\title{
Repositioning Secondary School Science Teachers' Pedagogical Beliefs and Information and Communication Technology (ICT) Classroom Practices for Sustainable Science Education in Post Covid-19 Era
}

\author{
Adah, Stephen Akomaye \\ Department of Curriculum \& Instructional Technology, Faculty of Education \\ Cross River University of Technology Calabar \\ steveadah80@yahoo.com
}

\begin{abstract}
In today's global Education system, science education is much more than fact-based knowledge. Science education becomes meaningless and incomprehensible for learners if they are unable to relate it with their lives. This paper critically examines some issues and challenges of secondary school science teachers' pedagogical beliefs, information and communication technology (ICT) classroom practices, Covid-19 pandemic and the need to adopt science, technology and society approach for delivery of Science Education for sustainability in the post covid-19 Era. The paper concludes with recommendations for the overall improvement of Science Education in Nigeria. Keywords:Science Teachers, Pedagogical beliefs, information and communication technology, class room practices, post-covid 19 era.
\end{abstract}

DOI: $10.7176 / \mathrm{JEP} / 13-6-02$

Publication date: February $28^{\text {th }} 2022$

\section{Introduction}

Education in its comprehensive notion means getting knowledge, skills, values and aspirations. It means learning something or acquiring some knowledge, skills values or aspirations. The processes of acquiring the education, according to Obanya (2012) could be incidental learning, informal education, non-formal education and formal education. Incidental learning is learning occasioned by some special (usually un-intended) incidents e.g. one's personal experience or experience of other people. Informal education is learning that occurs in the course of ones normal activities. It is usually unplanned, not necessarily organized by the school, has no curriculum and no specific teacher. It may come as general information or side effects of some activities like taking part in a meeting. Non-formal education is more or less organized learning. It is planned, usually for out of school learners who had missed earlier opportunities to get education. Adult education learners use non-formal mode to retrieve missed opportunities, sometimes apprenticeship schemes are classified as non-formal mode of education, even though apprenticeship may be highly formalized, (Obanya, 2012). Formal education is a formalized, regulated and planned form of education. It has planned programme of activities in the form of curriculum and is targeted in terms of content, clients, objective/outcomes etc.

Science education is a component of formal education given at all levels of education (i.e. from primary to tertiary). Science education on its own is the field concerned with sharing science contents and processes with individuals (Ugwu and Nwagbo, 2019). The field of science education comprises of science content, social sciences and some teaching pedagogy (Berube, 2008). According to Pember and Humbe (2009) science education is a process of teaching or training especially in school to improve one's knowledge about environment and to develop attitudinal characteristics. Science education has been recognized worldwide as a pre-requisite for technological development and no country can be globally recognized without talking about it scientific advancements (Obanya, 2012).

The overall importance of education to mankind is obvious. Hence, the United Nations Report (2010) highlighted education as a basic right and need which is significant in the accomplishment of improved living. Good education guarantees skilled and dynamic citizens, no nation can afford to neglect education especially science education at any level and hope to thrive in any field of human endeavour. This is because science education occupies a central position in producing resources needed for socio-economic, scientific and technological development and growth of any nation (Okigbo \& Okoli, 2016, Osuafor \& Okonkwo, 2013). Therefore, Nigeria like all other developing nations needs a re-orientation in her scientific and technological development, if she intends to be relevant and remain thus in the dawn of the third millennium. The new direction being sought is an enrichment programme in the area of teachers' pedagogical beliefs and ICT classroom practices for the sustainability of science education in our secondary schools in the post covid-19 Era.

The advert of the digital age has dramatically transformed every aspect of human life such as the way we work, the way we play, the way we live, the way we teach and learn. Thus, there is need to re-examine some of the classroom practices of the science teachers with the view to redressing, strengthening, improving and making 
them much better to equip learners with necessary knowledge, skills and attitude which will enable them to interact meaningfully with the environment and also solve life problems in the society. In the past decades, research on teaching and learning has been focused on teachers' subject area content knowledge and the method of knowledge transfer to students (Selvi, 2010, Lefebure, Deaudelis \& Loiselle, 2016).

For some, these researches are acknowledgements of the complexity brought about by the teaching process which aims at contributing to the empowerment of teachers, the enhancement of the teaching status and the improvement of the Pedagogical Content Knowledge (PCK) of teachers. It has been recognized that the foundation of science is thought to be the amalgam of a teacher's pedagogy and understanding of content such that it influences his/her teaching in ways that will best stimulate student learning for understanding. This emphasis on PCK is justified based on the assumption that PCK can make a significant impact on the quality of instruction that students receive and thus the quality of learning students experience on the classroom.

\section{What then are teachers' pedagogical beliefs?}

Pedagogical beliefs refer to preferred ways of teaching by teachers. These beliefs have been categorized into the knowledge transmission and the knowledge construction views (Teo, 2010).

Teachers who embrace the knowledge transmission view are inclined to prepare and conduct lessons in a teachercentred and content-oriented manner. They prefer didactic instructions and act as the sole provider of knowledge. Students accordingly, act as passive recipients of content knowledge. In contrast, the knowledge construction view advocates that students should actively make sense of their learning experiences while teachers design meaningful learning experiences and scaffold students' sense making.

According to Wong \& Chan (2009) teachers who hold the constructivist view tend to emphasize more students-centered activities that facilitate students' knowledge through active self-reflection, peer interaction and meaning-making process. In the same vein, Caine (2012) alluded that knowledge construction view tend to capitalize on students' natural curiosity in order to promote an attitude of discovery, which allows students to find out for themselves how and why certain phenomena occur, develop and organize classroom activities that emphasize an active role of the learners to construct their own understanding by interacting with the environment around them; provide learning materials and arrange activities in line with students interest and attitude, bearing in mind their individual differences.

Ertmer (2015) defined pedagogical beliefs as personal views a teachers holds regarding his/her teaching process and differs from one teacher to another. Pedagogical beliefs have personal core principles that do not change, but the beliefs around these principles must be able to adapt to the environment and students' needs. Practices in the classrooms need to change and therefore teachers' beliefs need to adjust with them for effective use of ICT in classrooms.

Information and communication technology is increasingly becoming one of the building blocks of modern society and is now considered as one of the indices for assessing level of development in very society. Many countries of the world today regard the acquisition of ICT skills as part of their core education, alongside reading, writing and numeracy for effective teaching and learning (Teo, 2010). In support of this Nwagbo and Uguanyi (2014), pointed that ICT has powerful implication on teaching and learning process and its usage is becoming increasingly vital due to the global nature of the twenty-first century teaching and learning. According to Lefebure, Deaudelin and Loiselle (2016) the use of modern technology offers good opportunity for improving not only teaching and learning but also effective communication between teachers and students. These potentials have implications for education in the sense that they will bring about changes in teaching methodology in line with the current science and technology demands and in response to post covid-19 pandemic era.

\section{The emergence of covid-19 and associated consequences on economic and education:}

On the $31^{\text {st }}$ December, 2019, the world Health Organization was informed of some cases of pneumonia of unknown cause in Wuhan City of China. A Novel Corona Virus was identified as being the cause by Chinese authority and later named Covid-19 on the $7^{\text {th }}$ January (WHO, 2020). From then the virus began to spread all over - China to Europe and finally Africa and Nigeria our own country. In Nigeria, the first case of Covid-19 was reported in Lagos State on the $27^{\text {th }}$ of February, 2020, and since then covid-19 has spread to all parts of the country, with each state recording some number of cases and deaths.

Undoubtedly, Nigeria, home of Africa's largest economy, is facing severe consequences from the surge of Covid-19. After undergoing recession in 2014-2016, the country was finally experiencing progress in its oil exports, resulting in overall financial recovery but unfortunately the emergence of the pandemic has indeed affected the country negatively. The country's dependency on oil export, along with the inevitable effect of the prolonged lockdown are two reasons for Nigeria's economic downturn with very great consequences. On the citizens, covid19 affect different people in different ways, some people develop mild to moderate illness and recover without hospitalization while some do not. Most common symptoms include (i) fever (ii) dry cough (iii) tiredness while less common symptoms include aches, sore throat, diarrhea, connectivity, headache loss of taste or smell skin 
rashes, discoloration of fingers or toes (Adnan, 2020).

Most people infected with the covid-19 virus experienced mild or moderate respiratory illness and will sometime recover without requiring special treatments. However, older people and those with underlying medical problems like diabetes, chronic respiratory diseases and cancer are more likely to develop serious complication if infected with covid-19 (WHO, 2020). Some preventive measures for the coronavirus include regular washing of hands, use of alcohol-based sanitizers, social distancing, use of facemasks, avoiding closed contact with infected persons, proper hygiene among others. (WHO, 2020). Today, vaccines have been made readily available for Nigeria citizens at no cost, but however, there are some misgivings about the vaccine which make many people to be very hesitant to take the vaccinations.

\subsection{Economic consequences}

The Covid-19 pandemic exposed the fundamental weakness of Nigeria's economy. By the time the country recorded its index case on $27^{\text {th }}$ February 2020, its economy was already characterized by a poverty-stricken population with over $40 \%$ living below the poverty line according to the National Bureau of Statistics. A part from this, there was overwhelming evidence of a weak and neglected healthcare system obviously to cope with the fallouts of the novel pandemic as well as a near-prostrate economy that was neither able to support the different sectors nor provide palliatives for its teeming population.

These were compounded by the drastic fall in the price of oil with debilitating consequence on the national budget and the economy as a whole. Oil prices between January and April 2020, plummeted from about $\$ 64$ per barrel to below \$20. In fact, on 20 April 2020, the futures for oil US benchmark went into the negative territory meaning that for the first time in history, producers were to pay traders to take oil off their hands. The price of Nigeria's oil benchmark (the Brent Crude) was luckier although still crashed to $\$ 19$ per barrel (Udemezue, 2020). This obviously had grave implications for the country given its almost total dependence on incomes from oil exports for its foreign exchange earnings. As the pandemic persisted globally, people were no longer travelling as several countries placed their economics on lockdown essentially to prevent the rapid spread of the virus. This unfortunately led to a sustained fall in the demand for both aviation and automobile fuel, which also affected Nigeria's net oil revenue by extension its foreign reserve. This aside, there were also supply shocks in the global supply chain as many exporters shut down their factories with almost every country closing its orders. Considering that Nigeria's economy is mostly import dependent, it was only a matter of time before it began to witness shortages in crucial supplies like pharmaceuticals, spare parts, construction materials and finished goods (Ozili, 2020).

The immediate consequences of these were a serious shortfall in government revenue resulting in an inability to meet its obligations. And worst hit was the 2020 national budget, which was predicted on an oil price of $\$ 57$ per barrel and a production quota of 1.7 million barrels. With the almost total collapse of oil prices, the entire budget had to be repackaged to reflect the new reality. For instance, the oil benchmark was reduced to $\$ 28$, while the production quota was brought down to 1.4 million barrels. Government also had to embark on massive eternal borrowing to the tune of $\$ 5.5$ billion essentially to fund it national budget. (Iwuagwu, 2020)

Government's inability to meet its financial obligations at this time also had implications for the citizens who immediately began to show resistance to several government policies and programmes, especially those targeted at the lockdown of the economy to combat the rampaging Covid-19 pandemic. In Lagos, Nigeria's economic and commercial capital for instance, the citizens resistance led to the emergence of several armed gangs including the 'one million boys', who operated freely within the city's slum and suburbs terrorizing citizens and dispossessing them of their monies and other valuables. There were also pockets of demonstrations by citizens in several other cities, who openly complained of hunger amidst the lockdown of their economic activities. This ugly situation was further exacerbated by the poor handling of government palliatives, which in most cases were either distributed along political party lines or mostly to favour political party faithful and stooges of people in government.

\subsection{Social and educational impact}

The social impact of coronavirus and the actions taken to reduce its spread were severe, such that the circumstances resulted in a unique situation in which people had to change their routine lifestyles, their activity patterns, the way they work and how they travelled which are three facets of daily life (Mathijs, 2020). Consumer demand was also curtailed directly through measures that prevented consumers from spending money on non-essential goods and services.

The Covid-19 equally affected the education sector very seriously worldwide leading to the near-total closures of secondary schools, colleges and universities. The Nigerian Government, like many other nations, went into temporary closure of schools in an attempt to reduce the spread of Covid-19. School closures impacted negatively not only on students but also on teachers, and parents with far-reaching economic and societal consequences. The impact was more severe on disadvantaged children and their families as well as private teachers who lost their means of livelihoods to the virus. The Covid-19 pandemic stalled academic activities at all levels of education, 
lost of academic year and reduced students interest in academic activities. Although the lockdown measure, while very necessary to minimize lost of life, and danger posed by the diseases, created significant economic anxieties with adverse consequences on human social lives and activities, food security and hunger, social and household welfare.

\section{How to improve science teachers' pedagogical beliefs and ICT classroom practices in post covid era}

Teachers' competency in science teaching and learning is an important factor in determining the success of every teaching session and the ultimate goals of teacher professional development is enhanced student learning. Quality teaching requires purposeful and deliberate planning of science instruction that results in a coherent learning experience for students. This implies that teachers must justify the importance and structure of the content they are teaching, their selection of pedagogical techniques and how this combination effectively attends to the teaching context as it relates to meeting student-learning needs (Gess-Newsome, Carlson, Gardner \& Taylor, 2010). Most importantly, teachers must also realize that it usually takes a long time and considerable evidence for students to change their ideas about the nature of science. The ability and wisdom in handling learning activities will have direct impact on students' involvement in learning activities.

According to Osborne \& Collins (2013) science is the amalgam of cognitive activities that include emotional engagement and practical experiences hence the need for hands-on and minds-on activities in science classroom to provide a wide range of scientific skills from basic to analytical skills. Wallice and Loudon (2015) raised the importance of practical work in classroom practices in order to bridge the gap between school science and real science. There is therefore a need to shift science education from scientist focused curriculum to learner focused by changing socially isolated content to interesting, engaging and relevant content. This can be achieved through Science Technology society approach (STs) Science technology society (STS) approach has potentials to make science relevant and practical for students because its vision is rooted in the notion of developing a scientifically literate citizenry who can take comfortable decisions about the socio-scientific issues that impact on their lives. It targets science education for all children and not specifically for future scientists (Rennie, Goodrum \& Hackling, 2014).

Pedrett and Hodson (2010) broadly categorized the goals of the STS approach into two areas personalization of learning and politicization of science education. Personalization goals of STS emphasizes on constructivist philosophy of learning which focuses on learners' own experiences. The politicization aspect of STS focuses on social enterprise, where students get the opportunity and freedom to play their role in society. Dillan and Grace (2014) suggested many instructional techniques for STS teaching among which are visual simulation, visual laboratories, co-operative learning, e-debates, action project, survey, case studies, self-regulated learning etc. students' involvement and actions during learning process result in improvement of students' knowledge, higher order skills, creativity, attitude towards science, process skills and ability to apply concepts in new situation (Zin, 2017).

In this post Era of Covid-19, science classroom practices should go beyond only physical contact with the students. Students should be taught and engaged through computer simulated instructions such as virtual laboratory and virtual fieldtrip. Computer simulation give students the opportunity to observe real world experiences even from a distance. Apart from the structured learning provided by the laboratory, the simulations also motivate the students to further explore the underlying concepts through process of self-directed learning. The national science education reform advocates that science teachers should engage students in doing and thinking about inquiring and review emphasis on teaching about the nature of science. Therefore, teachers require new orientation in line with emerging trends in science education for its sustainability in the post- Covid-19 Era.

\section{Conclusion}

Science teaching and learning depends largely on the degree of professional and pedagogical competence of teachers. There is therefore the need to redefine teachers' professional development for sustainability of Science Education in the post covid-19 Era.

\section{Recommendations}

The following recommendations are made for sustainability of Science Education.

1) Science teachers especially those in secondary schools should endeavour to create classroom environment that encourages critical thinking experience through engagement of students in creative activities, openended questions, self-directed learning among others.

2) Science and technology teaching methods should be modernized to bring life back into science. To achieve this, a policy on standards of professional development of teachers should be implemented, requiring teachers to maintain a reasonable knowledge of pedagogical content knowledge and skills.

3) Government should call on curriculum planners to reform curricula to incorporate teaching, strategies that will encourage regular and compulsory use of Information and Communication Technology (ICT) as 
well as other creativity-building strategies in secondary schools.

4) Teachers who display creativity in their method of teaching should be encouraged by way of incentives.

5) Training programme should be organized for science teachers to acquaint them will emerging trends in teaching and learning.

\section{References}

Aaron, K. (2020). Coronavirus cause: origin and how it spreads. Retrieved from https//www.medicalnewstoday.com/articles/coronavirus.causes. (Google scholar).

Adnan, A. (2020). Nigeria ramps up response efforts to smash coronavirus. Retrieved from https///www.aa.com.tr/en/Africa/nigeria-ramps-up-response-efforts-to-smash coronavirus/1771922 (Google scholar).

Berube, C. T. (2008). The unfinished quest, the plight of progressive science education in the age of standards charlotte, NC; Information age publishing Braund.

CDC. (2020). Coronavirus disease 2019 (COVID-19) and you. Retrieved from www.cdc.gov>2019ncov $>$ downloads $>2019$-ncov-factsheet). (Google scholars).

Ertmer, P. A. (2015). Teacher pedagogical beliefs: The final frontier in our quest for technology integration? Educational technology research and development 53(4), 25-29.

Lefebure, T., Deaudelin, R. \& Loiselle, W. (2016). Teachers beliefs and practices in technology-based classrooms: A development view. Journal of Research on Technology in Education, 42(2), 482-515.

NCDC. (2020a). First case of coronavirus disease confirmed in Nigeria. Retrieved from https://ncdc.ng/news/227/first-case-of-corona-virus-disease-confirmed-in-nigeria (Google scholars).

Obanya, P. (2012). Eight practical ways of moving education forward for Sustainable Human Development. Braced Commission Education Summit. Port Harcourt $15^{\text {th }}-17^{\text {th }}$ November, 2012.

Osborne, J. \& Collins, S. (2013). Pupils' views of the role and value of the science curriculum: A focus-group study. International journal of Science Education, 23(5), 441-467.

Pedretti, E. \& Hodson, D. (2010). From rhetoric to action: Implementing STS Education through action research. Journal of Research in Science Teaching, 32(5), 463-485.

Pember, S. T. \& Humbe, T. T. (2009). Science education and national development. Being a paper presented at the ASSUTIBS, Maiden National Conference at CEO Katsina-Ala $6^{\text {th }}-9^{\text {th }}$ October, 2009.

Rennie, L., Goodrum, D. \& Hackling, M. (2014). Science, teaching and learning in Australian Schools: Results of a national study. Research in Science Education 31, 455-498.

Teo, C. (2010). Beliefs about teaching and uses of technology among pre-service teachers. Asia-Pacific Journal of Teacher Education, 32(2), 163-174.

Ugwu, T. U. \& Nwagbo, C. (2019). Enhancing students' interest in Basic Science using Guided Inquiry Instructional method. Journal of the Science Teachers Association of Nigeria (STAN) 54(1), 121-129.

UNESCO (2009). ICT competency standards for teachers-implementation guidelines. http://www/unesco.org/competency-standards-teachers.

United Nation's Children Fund (UNICEF), UNICEF key messages and action for COVIC-19 prevention and control in school, March 2020.

Wallace, J. \& Louden, W. (Eds.) (2018) dilemmas of science teaching London: Routledge, Falmer.

Wong, B. \& Chai, C. S. (2010). Asian personal epistemologies and beyond: overview and some reflections. The Asia-Pacific Education Researcher, 19(1), 1-6.

Zin, S. M. (2017). Reforming the science and technology curricular: The Smart school initiative in Malaysia. Prospects xxxiii, 39-50. 